\title{
Work Ethics and Social Responsibility: Actual and Aspiration
}

\author{
Ali Awad Alwagfi \\ Business Management, Jadara University, Jordan \\ Nader Mohammad Aljawarneh \\ Business Management, Jadara University, Jordan \\ Khaled Abdalqader Alomari \\ Business Management, Jadara University, Jordan \\ E-mail: n.jawarneh@jadara.edu.jo
}

Received: Sep. 8, 2019 Accepted: Nov. 5, $2019 \quad$ Published: January 1, 2020

doi:10.5296/jmr.v12i1.15794 URL: https://doi.org/10.5296/jmr.v12i1.15794

\begin{abstract}
This study aims at investigating the reality of social responsibility, and its ethical dimensions in educational business organizations in addition to knowing the prevailing advantages and disadvantages. The sample of the study consisted of northern Jordanian universities were 210 male and female as respondents to a questionnaire. 200 questionnaires were valid for statistical analysis in order to achieve the purposes of this study; the researcher adopted a descriptive approach. This study utilized a tool to measure the social responsibility, and its ethical dimensions in private northern Jordanian universities. The study concluded that the correlation between social responsibility and ethical dimensions were statistically significant. In light of the aforementioned findings, the study recommended the raising employees' morals and motivating them in ethical ways, in addition to developing a clear plan applied by educational organizations to apply and practice social responsibility.
\end{abstract}

Keywords: Social responsibility, business ethics, administrative ethics. 


\section{Introduction}

Social responsibility has become one of the great challenges facing business organizations in the community, as it brings an additional burden on all levels' managers to become one of the most important constituents, as it is the optimal way for the success of the organization and achieve their goals in the survival, continuity, and growth. Ethics distinguishes between rights and wrong, legal and illegal, which means it's a social value like other values such as the right, beauty honesty, truthfulness and others that control the behavior and choices and actions of business organizations towards clients (Fassin et al, 2011).

This study is concerned with the reality of social responsibility and work ethic in the Northern Jordanian private universities. This research value is illustrated by the role of social responsibility towards all internal and external dealers with the organizations to establish ethical controls in everyday transactions, in order to improve performance in to achieve organization's objectives in the long term. As there is a lack of studies on this topic looking at this topic, particularly in educational organizations; this study aims to contribute and enrich social responsibility literature (Frynas, 2005). In addition, this study aims at highlighting the social responsibility and identifying concept and components of the Jordanian private universities throughout the research. Another objective of this study is to identify the strengths and weaknesses related to social responsibility in the Jordanian private universities. It also aims to illustrate the social responsibility role in resolving ethical business problems in the Jordanian private universities. Respondents opinions regarding the extent of interest in certain dimensions of social responsibility and work ethic compared to other dimensions the were analyzed; and theses respondents were mainly tutors that are holding doctoral and master's degrees, and administrators. The study problem concentrates on the importance of the officials and employees' awareness in Jordan's private universities regarding social responsibility, and its reflection on the business ethics, and overcoming issues by answering the following questions: Is there an awareness of social responsibility among workers in the study sample? Is there an understanding of the business ethics among the respondents? What is the extent of standards application of social responsibility and business ethics?

Aiming to answer the previous questions, the following hypotheses were proposed:

H1: There is no high degree of awareness and positive attitudes of social responsibility among the respondents in the Northern Jordanian private universities.

H2: There is no variation in the answers of the respondent tutors of doctoral and master's degree holders and the administrative staff on the dimensions of social responsibility and business ethics.

\section{Theoretical framework}

Social Responsibility: According to Fassin et al (2011), the responsible organizations will be socially acceptable in front of special interest groups in the organization and activities are also responsible to the community as a whole. The influence of these groups is affected by the organization's achievements and objectives. Nowadays, as stated by Friedman (2007). One of the main demands of any society towards any business organization is social and moral 
responsibility towards the society, moreover, another demand is to prioritize customers, employees, consumers and organization dealers over making profits (Frynas, 2005). Responsibility is perceived as an ethical behavior that is linked to the environmental pollution issues, unemployment, inflation, and increasing poverty among some social minorities, and established of social responsibility in this aspect of the failure of the business organizations to implement its duties towards society the Arab Society of Certified Public Accountants (Fassin et al, 2011).

Al-Omari, et al (2020) defines social responsibility as a set of decisions and actions taken by the organization to achieve the desired goals and values of the community, which are part of the direct economic organization management benefits that are part of its strategy. According to Friedman, M. (2007), there is an overlapping relationship between social responsibility and business ethics, which appeared in late seventies of the last century, when the focus on the ethics management as well as social responsibility and efficiency began. After the seventies, social responsibility became a moral dimension interferes with ethics in general management. McWilliams et al (2006) states according to Bowen social responsibility: Business men commitment by applying polices and decision making, and doing according to the goals and the values.

The ethics contradicted with some practices' values in the whole community and may raise the values of the courts, which may be a return to the ignorance of these results. Differences in this behavior may be due to the lack of universal standards of business conduct, as perhaps depending on the geographical areas vary, or ethnic groups. Also, these differences may be due to differences in individual values between management and stakeholders for example (McWilliams et al, 2006). Administrative ethics: A set of behavior principles and rules that distinguish between what is good and bad, true and error, furthermore, they are a guide to behavior and decision-making. Ethical standards can be divided into three groups: Maximizing self-interest, self- centered manager $100 \%$, maximizing the public interest / community where the public interest control any decision or conduct, having a general principle to distinguish between right and wrong (Rahbek \& Neergaard, 2009).

Ethics rules: They are divided into three levels: the individual level, the corporate level, and the community level (Rahbek \& Neergaard, 2009). Ethics as values and standards on which the society relies to distinguish between what is right and what is wrong. Moreover, there are four elements which constitute work ethics and social responsibility: Individual, organization, law, and society (Reamer, 1998). These four elements interact with each other, therefore, strongly affect each other in terms of the strength and direction; as decision-maker ethics affect the organization and, thus, affect the clients (Vallaster et al, 2012). Ethical standards are characterized by dealing with what have serious impacts on enhancing humanity, therefore, ethical standards must understand the self-interests and not inconsistent with it (Al-Omari et al., 2018). Business ethics are important for occupancy positions, confirmed by management; due to serving as the individual self-censorship; as one cannot distinguish between right and wrong in his behavior at work. It also attracts highly rated individuals as they will also contribute to the organizational ethics, given that organization derives its ethics from employees (Velasquezet \& Velazquez, 2002). As regarded by 
Vallaster et al (2012), business ethics are important human behavior principles, associated with good behavior or good standards, and bad behavior or bad standards.

Regarding the relationship between ethics and performance, most of the literature of the "business ethics" indicate that ethics are important and beneficial to work in the long term at least were not important and beneficial in the short term. In addition, ethics are the key element which depends upon the success and development of institutions in the long term. Therefore, work will lack effectiveness if there was an absence of trust and honesty, moreover, transaction costs will be increased, especially legal costs. Trust, particularly, plays an important and vital role in work, and its role appears in effective working relationships and good company practice. Honesty is also important on organizations, yet it is not easy to be achieved; as there is discrepancy between honesty and personal interest (Morsing \& Schultz, 2006).

From am utilitarian perspective, there is nothing wrong in using the honesty as a policy, means of self-preservation, or to earn money provided that no one is harmed. Despite that, businessmen who do not believe in ethical behavior and only pretending will have to bear dangerous impacts on their customers and other stakeholders (Rokhman, 2010). Hence, using honesty as a policy and not as a virtue, could lead to counterproductive. And despite the fact that a lot of the business they are doing the right thing because it is the thing that should be done, or to link their reputations in honesty regardless of the results, others cannot risk the loss of their reputations and financial losses incurred because they are not honest. Institutions that operates in a manner unethical to continue and not be able to, but they are exposed to the risk of loss of reputation, also loss of activity (Spence \& Rutherfoord, 2003).

It should be noted that not all ethics systems are suitable for work. For example, the moral order which emphasizes altruism and self-denial and anti-material, may lead to obstruction of economic and social progress and may interfere with work. Suppose, for example, that there is a butcher is altruistic and sells the meat in a poor town of less than marginal cost. It will not be long until it loses the butcher and his work becomes more than ever before shambles. Therefore, it must be distinguished between ethics as a target and ethics as an impediment and an obstacle to work (Moir, 2001).

The company is not seeking mission to profit to seeks to apply ethical goals only and are not only mission for companies to seek profit, but the company should achieve its goal of maximizing profits through a commitment to ethical means. In this context, the objectives associated with the work ethic, the ethics becomes important in the work and means of implementing those goals. The market, which is the institutional base to work, provides opportunities for ethical behavior by imposing costs on the institutions and individuals who violate ethical standards (Aljawarneh \& Al-Omari, 2018). It can also the person applied the ethics at work indirectly, through the improvement of the living conditions of individuals through the employment of ordinary people in order to feel comfortable and trust in life (Welford, 2004).

When participates in achieving security and economic prosperity for individuals, then the business can succeed in reducing unethical behaviors. Poverty, unemployment is the leading cause of criminal activities and unethical behaviors, other examples of the application of the 
ethics in business is the commitment of many institutions in recent years a policy of equal opportunities in order to assist individuals with disabilities, and people with ethnic backgrounds oppressed. And such a policy will lead to the correct meaning of work and contribute to the establishment of sound the ethics (Aljawarneh \& Atan, 2018).

Notwithstanding the foregoing, the view that the work is useful to ethics can be asserted in part. However, the trading community may significantly contribute to the emergence of immoral behaviors such as greed and betrayal Banks (2008). As noted previously, although the markets raised goods and services that improve the quality of life and possibly make us more prosperous, they raised goods and services that do not already need. Apart from the damage to the environment and to instill the adjectives envy and jealousy in some souls, they may encourage the poor to commit criminal acts and actions contrary of ethics. It is clear that the relationship between the ethics and work closely and variable relationship. It also cannot be separated from each other either (Rokhman, 2010). In some cases, reinforce each other, and in the other as mutually exclusive. When mutually exclusive, they are causing problems for the community, if not for the work itself. Perhaps we find that the best way to settle the conflict between the two can only be through collective action, which depends on the incentives that are granted to institutions and individuals, and the sanctions that are imposed on them in order to push them to act in an ethical manner. It does not represent a major problem, where most of the business seeks to do the right thing because of financial interests or because it is simply the right thing to do (Spence \& Rutherfoord, 2003).

\section{Methodology}

This study can be classified as an exploratory and field study. It is considered exploratory because it attempts to explore the effect of the social responsibility and ethical dimensions. Moreover, field study because it will base on primary data collection from a questionnaire develops to identify the impact of social responsibility and ethical dimensions. A quantitative approach has been used in this research in order to identify the role of social responsibility on ethical dimensions. In addition, primary data collected from the questionnaire.

The study population consisted of the educational sector in four Northern private; Jadara University, Irbid National University, the University of Jerash, and Ajloun National University. A random sample 200 employees from four universities was selected, with an average of 50 from each university. Doctoral and master's degree holders were $50 \%$ of the sample, where the other half was administrative staff. For the sake of collecting data, a questionnaire was developed consisting of twenty-paragraph, as the answers will reflect the reality of behaviors, daily practices, and the extent of social responsibility commitment through a set of ethical standards. For data analyzing, arithmetic means and standard deviations were used and then obtaining results.

For ensuring the questionnaire validity, and the matching degree between paragraphs of what they were developed for, it was evaluated by 15 members of the community study to identify the degree of awareness and clarity of paragraphs questionnaire and some of the paragraphs were rewritten to be more appropriate. The questionnaire was also evaluated regarding 


\section{$\triangle$ Macrothink}

Cronbach's alpha coefficient for internal consistency where it was $88 \%$ and considered to be acceptable. Total sample answers are illustrated in the following table:

\section{Results}

Table 1 . The total sample answers generally $\mathrm{n}=190$

\begin{tabular}{|c|c|c|c|l|l|}
\hline $\begin{array}{l}\text { Strongly } \\
\text { Reject }\end{array}$ & Reject & $\begin{array}{l}\text { Moderately agree } \\
\text { degree }\end{array}$ & Agree degree & $\begin{array}{l}\text { High agree } \\
\text { degree }\end{array}$ & \\
\hline 89 & 76 & 9 & 10 & 6 & Repetition \\
\hline 0 & 20 & 40 & 60 & 80 & Points \\
\hline
\end{tabular}

Given the previous table, and depending on the evaluation key, it can be seen that 6 respondents received a bad total mark 80; indicating the presence of ethical problems at work, and would prefer not continue their work within the organization, and so considering that the first column strongly reject weigh 4 points, and the process of multiplying this number 20 shows that the number of paragraphs. It can also be seen that 10 respondents have received a total of 60 , and, therefore, need to raise their morals. 9 respondents received a total of 40 , indicating the medium level of ethical, and therefore considered to be positive. While came in 76 of the respondents, the level of ethical represent very good in their access to the total 20 of the points. And it appears that there are 89 respondents were distinguished elite as the sum of their points is equivalent to zero. Table 2 the following shows sample distribution and percentages for answering

Table 2. The distribution of the sample and its percentages $n=190$

\begin{tabular}{|c|c|c|c|c|c|c|c|c|c|c|}
\hline \multicolumn{2}{|c|}{$\begin{array}{l}\text { Strongly } \\
\text { Reject }\end{array}$} & \multicolumn{2}{|c|}{ Reject } & \multicolumn{2}{|c|}{$\begin{array}{l}\text { Moderately } \\
\text { agree degree }\end{array}$} & \multicolumn{2}{|c|}{ Agree degree } & \multicolumn{2}{|c|}{ High agree degree } & \\
\hline Rep. & $\%$ & Rep. & $\%$ & Rep. & $\%$ & Rep. & $\%$ & Rep. & $\%$ & Sample \\
\hline 65 & 34.21 & 25 & 13.15 & 2 & 1.05 & 2 & 1.05 & 1 & 0.52 & Tutors \\
\hline 13 & 6.84 & 62 & 32.63 & 7 & 3.68 & 8 & 4.21 & 5 & 2.63 & Administrators \\
\hline 78 & 41.05 & 87 & 45.78 & 9 & 4.73 & 10 & 5.26 & 6 & 3.16 & Total \\
\hline
\end{tabular}

As shown in table 2 above in the Tutors sample, the number of 1 of these respondents as a percentage of 0.52 should be left to work as suffering from an ethical problem was the winning total 80 versus 5 of the administrators by percentage 2.63 obtained with a bad estimate. There are 2 of the sample Tutors percentage 1.05 received a total of 60 and these need to raise awareness and lectures on business ethics, versus 8 of the sample administrators and percentage 4.21 of the same level. Were 2 of the Tutors and the percentage 1.05 medium ethical level as it was a positive achievement 40 versus number 7 as a percentage 3.68 ? Was 25 of the sample Tutors percentage 13.15 at the ethical level is very good as they get 20 points, compared to 62 of the administrators percentage 32.63 of the same ethical level is very good. Finally, it was 65 of Tutors percentage 34.21 hold a best estimate and considers where the elite of the total scored zero, compared to 13 of the administrator's percentage 6.84 of the same distinguished level. These figures indicate that there is a clear contrast between the responses 
of Tutors and administrators answers, where answers of Tutors more positive and better ethical level. With regard the arithmetic means and standard deviations the following table shows:

Table 3. The arithmetic means and standard deviations for members of the sample

\begin{tabular}{|c|c|c|}
\hline $\begin{array}{l}\text { Standard } \\
\text { deviations }\end{array}$ & Means & Paragraph \\
\hline 1.7 & 3.5 & 1 \\
\hline 1.8 & 3.7 & 2 \\
\hline 1.9 & 3.5 & 3 \\
\hline 2.1 & 3.2 & 4 \\
\hline 1.5 & 3.5 & 5 \\
\hline 2.6 & 3.9 & 6 \\
\hline 1.6 & 3.9 & 7 \\
\hline 1.8 & 3.6 & 8 \\
\hline 1.1 & 3,7 & 9 \\
\hline 1.4 & 3.7 & 10 \\
\hline 1.4 & 3.4 & 11 \\
\hline 1.7 & 3.6 & 12 \\
\hline 1.4 & 2.2 & 13 \\
\hline 1.4 & 3.3 & 14 \\
\hline 1.9 & 3.8 & 15 \\
\hline 1.5 & 3.9 & 16 \\
\hline 1.4 & 3.2 & 17 \\
\hline 1.6 & 2.4 & 18 \\
\hline 1.8 & 3.2 & 19 \\
\hline 1.2 & 3.7 & 20 \\
\hline 1.645 & 3.445 & Total \\
\hline
\end{tabular}

As illustrated in table 3, arithmetic means of the sample answers were high with a total of 3.445 which is superior to the default center and of 2 and after that was the opposite values of the process. A total of 1.645 standard deviation indicates positive trends in social responsibility and business ethics by the respondents. The following table presents separate arithmetic means and standard deviations of the two samples: 
Table 4. Arithmetic means and standard deviations of the two samples

\begin{tabular}{|c|c|c|c|c|}
\hline \multicolumn{2}{|c|}{ Administrators } & \multicolumn{3}{|c|}{ Tutors } \\
\hline $\begin{array}{l}\text { standard } \\
\text { deviations }\end{array}$ & arithmetic means & $\begin{array}{l}\text { standard } \\
\text { deviations }\end{array}$ & $\begin{array}{l}\text { arithmetic } \\
\text { means }\end{array}$ & Paragraph \\
\hline 1.9 & 3.3 & 1.7 & 3.9 & 1 \\
\hline 1.6 & 2.8 & 1.6 & 3.8 & 2 \\
\hline 1.6 & 3.1 & 1.9 & 3.7 & 3 \\
\hline 1.8 & 2.0 & 1.1 & 3.9 & 4 \\
\hline 1.5 & 2.7 & 1.2 & 3.5 & 5 \\
\hline 1.7 & 3.2 & 1.4 & 3.9 & 6 \\
\hline 1.2 & 3.1 & 1.3 & 3.7 & 7 \\
\hline 1.9 & 2.6 & 1.3 & 3.5 & 8 \\
\hline 1.8 & 3.6 & 1.2 & 3.7 & 9 \\
\hline 1.8 & 3.1 & 1.5 & 3.6 & 10 \\
\hline 1.3 & 3.1 & 0,7 & 3.3 & 11 \\
\hline 1.9 & 2.8 & 1.6 & 3.2 & 12 \\
\hline 1.8 & 2.1 & 0.8 & 3.0 & 13 \\
\hline 1.9 & 2.9 & 1.5 & 3.8 & 14 \\
\hline 1.7 & 3.0 & 1.6 & 3.2 & 15 \\
\hline 1.6 & 2.8 & 0.9 & 3.6 & 16 \\
\hline 1.7 & 2.7 & 1.6 & 3.7 & 17 \\
\hline 1.9 & 2.4 & 1.2 & 3.1 & 18 \\
\hline 1.8 & 2.6 & 0.6 & 3.7 & 19 \\
\hline 1.9 & 2.3 & 1.1 & 3.9 & 20 \\
\hline 1.725 & 2.825 & 1.29 & 3.595 & Total \\
\hline
\end{tabular}

There are clear differences between the tutors' responses and the administrators' responses; as the arithmetic mean of the tutors was 3.595, which is high, and the standard deviation was 1.29 ahead of sample administrators, where it was the arithmetic mean 2.825 and a standard deviation was 1.725 . This result may be due to the superiority of the tutor's scientific level, and their familiarity with the concept of social responsibility and work ethic.

\subsection{Hypotheses test}

By reading the data contained in the table 3 in the regards with arithmetic mean and standard deviations shows that there is a degree of awareness and application of the concept social responsibility and business ethics, and attitudes were positive, where was the arithmetic mean of all the paragraphs refers to 3.445 and a standard deviation of 1.645, as this the arithmetic mean outperform lot far from the default mean 2. This result reinforces the first hypothesis: 
there is high degree of awareness and positive attitudes of social responsibility among the respondents in the Northern Jordanian private universities, therefore, hypothesis is accepted, and null hypothesis is rejected; as it states that: there isn't high degree of awareness and positive attitudes of social responsibility among the respondents in the Jordanian private universities in the north of the kingdom. Table 4 illustrates the arithmetic mean and standard deviations for both samples (tutors and administrators) that there is a clear divergence in the responses between them. While the arithmetic mean of the tutors' sample is high, scoring 3.595, and standard deviation 1.29, whereas the arithmetic mean of the administrators' sample was much lower, scoring 2.825 and standard deviation 1.725 . This result rejects the null hypothesis that states: there is no variation in the answers of the respondents Tutors of doctoral and master's degree holders and the administrative staff on the dimensions of social responsibility and business ethics. Moreover, main hypothesis must be accepted; indicating that there is a variation in the respondents' answers regarding social responsibility and business ethics dimensions.

\section{Findings, Discussion and Recommendations}

Based on this study results, it is concluded that there is a positive degree of awareness and understanding of social responsibility and work ethic, demonstrated by the arithmetic mean; as it was positive with a total of 3.445. This result is consistent to some extent with results of Visser(2008); Kurucz et al (2008). It was found that educational organizations are well interested and focused on the dissemination of social responsibility and work ethic concepts, and these findings are consistent with Maryam's bin Jima study results. This study also concluded that there is a difference in the degree of awareness and application of social responsibility and work ethics concept among high degrees' holders' tutors and between administrators, as the tutors' arithmetic mean scored 3.595, whereas administrators' arithmetic mean scored 2.825. Paragraph 13 in the questionnaire, which calls for the possibility of going out on some of the procedures and policies was the most negative, as is the arithmetic mean scored 2.2 and the result is positive reflections dedicated compliance with policies and procedures. The Paragraphs 18 that are looking to the subject of adulation for the heads has negative results have also been reaching the arithmetic mean 2.4. There is general consensus on the importance of social responsibility towards the workers inside the Jordanian private universities, and the importance of motivating workers and broadcast their morale. Another result of this study was the effective role to oversight in controlling the behavior of workers and this result is consistent with the results of the Al-Zakarneh (2012) study.

Based on these results, this study recommends increasing attention to social responsibility and ethical dimensions of work in business organizations due to its significant impact on the reality of organizations and its future. It also recommends to increase lectures and seminars regarding social responsibility. Moreover, this study recommends raising employees' morals and motivating them in ethical ways, in addition to developing a clear plan applied by educational organizations to apply and practice social responsibility. It is also recommended to spread noble values of cooperation, equality and justice among workers in order to form ethical foundations within the organization. Lastly, this study illustrates the need for senior 
management commitment to ethical rules as they role models for others, and work to increase loyalty, therefore, set mortality laws.

\section{References}

Aljawarneh, N. M. S., \& Atan, T. (2018). Linking Tolerance to Workplace Incivility, Service Innovative, Knowledge Hiding, and Job Search Behavior: The Mediating Role of Employee Cynicism. Negotiation and Conflict Management Research,11(4), 298-320. https://doi.org/10.1111/ncmr.12136

Aljawarneh, N., \& Al-Omari, Z. (2018). The Role of Enterprise Resource Planning Systems ERP in Improving Customer Relationship Management CRM: An Empirical Study of Safeway Company of Jordan. International Journal of Business and Management, 13(8), 86-100. https://doi.org/10.5539/ijbm.v13n8p86

Al-Omari, Z. S., Aljawarneh, N., Davut, S., \& Salah, A. (2018). The Impact of Marketing Mix Elements on Forming Mental Images about Islamic Banks in Jordan: An Empirical Study. OFFICIAL, 12, 54.

Al-Omari, Z., Alomari, K., \& Aljawarneh, N. (2020). The role of empowerment in improving internal process, customer satisfaction, learning and growth. Management Science Letters, 10(4), 841-848. https://doi.org/10.5267/j.msl.2019.10.013

Al-Zakarneh, B. K. (2012). Work ethic and their impact on the elite management in business organizations, the study of the Jordan Telecom companies. Journal of Baghdad College of Economic Sciences University, No. 33.

Banks, S. (2008). Critical commentary: Social work ethics. The British Journal of Social Work, 38(6), 1238-1249. https://doi.org/10.1093/bjsw/bcn099

Fassin, Y., Van Rossem, A., \& Buelens, M. (2011). Small-business owner-managers' perceptions of business ethics and CSR-related concepts. Journal of Business ethics, 98(3), 425-453. https://doi.org/10.1007/s10551-010-0586-y

Friedman, M. (2007). The social responsibility of business is to increase its profits. In Corporate ethics and corporate governance (pp. 173-178). Springer, Berlin, Heidelberg. https://doi.org/10.1007/978-3-540-70818-6_14

Frynas, J. G. (2005). The false developmental promise of corporate social responsibility: Evidence from multinational oil companies. International affairs, 81(3), 581-598. https://doi.org/10.1111/j.1468-2346.2005.00470.x

Galiby, D. M.,\&Amery, S. M(2016). Social Responsibility \& Business Ethics \& Society (5 Ed), Dar wail for Publication, Amman :Jordan.

Kurucz, E. C., Colbert, B. A., \& Wheeler, D. (2008). The business case for corporate social responsibility. In The Oxford handbook of corporate social responsibility. https://doi.org/10.1093/oxfordhb/9780199211593.003.0004 
McWilliams, A., Siegel, D. S., \& Wright, P. M. (2006). Corporate social responsibility: Strategic implications. Journal of management studies, 43(1), 1-18. https://doi.org/10.1111/j.1467-6486.2006.00580.x

Moir, L. (2001). What do we mean by corporate social responsibility? Corporate Governance: The international journal of business in society, 1(2), 16-22. https://doi.org/10.1108/EUM0000000005486

Morsing, M., \& Schultz, M. (2006). Corporate social responsibility communication: Stakeholder information, response and involvement strategies. Business ethics: AEuropean review, 15(4), 323-338. https://doi.org/10.1111/j.1467-8608.2006.00460.x

Najem, A.(2000). Ethics management in a changing world, the first edition, the Arab Organization for Administrative Development, Research and Studies series, Cairo, Arab Republic of Egypt.

Pedersen, E.R, \& Neergaard, P. (2009). What matters to managers? The whats, whys, and hows of corporate social responsibility in a multinational corporation. Management Decision, 47(8), 1261-1280. https://doi.org/10.1108/00251740910984532

Reamer, F. G. (1998). The evolution of social work ethics. Social work, 43(6), 488-500. https://doi.org/10.1093/sw/43.6.488

Rokhman, W. (2010). The effect of Islamic work ethics on work outcomes. EJBO-Electronic Journal of Business Ethics and Organization Studies.

Sabbagh, Z.(1986). The moral dimension in public service, Institute of Public Administration, number 48, Riyadh.

Spence, L. J., \& Rutherfoord, R. (2003). Small business and empirical perspectives in business ethics. Journal of Business Ethics, 47(1), 1-5. https://doi.org/10.1023/A:1026205109290

Vallaster, C., Lindgreen, A., \& Maon, F. (2012). Strategically leveraging corporate social responsibility: A corporate branding perspective. California management review, 54(3), 34-60. https://doi.org/10.1525/cmr.2012.54.3.34

Velasquez, M. G., \& Velazquez, M. (2002). Business ethics: Concepts and cases (Vol. 111). Upper Saddle River, NJ: Prentice Hall.

Visser, W. (2008). Corporate social responsibility in developing countries. In The Oxford handbook of corporate social responsibility. https://doi.org/10.1093/oxfordhb/9780199211593.003.0021

Welford, R. (2004). Corporate social responsibility in Europe and Asia: Critical elements and best practice. Journal of corporate citizenship, (13), 31-47. https://doi.org/10.9774/GLEAF.4700.2004.sp.00007 